\title{
PREFÁCIO - HOMENAGEM À MARIA JOSÉ ROSADO NUNES
}

\author{
Silvia Pimentel*
}

É uma honra e uma alegria participar desta homenagem à Maria José Rosado - a querida Zeca, grande feminista, socióloga e colega da PUC, onde leciona Sociologia da Religião. Reúne belos textos de estudioso e estudiosas militantes que, através de reflexões críticas sobre Deusas, Deuses, Santas e Santos, fé, teologias, religiões e a Bíblia, tanto contribuem para a superação do patriarcado que por séculos e séculos oprime as mulheres.

Aceitei o convite de juntar algumas palavras iniciais a essa coletânea, na qualidade de jurista feminista, não apenas pelo enorme bem querer que me une à Zeca, mas pela admiração e reconhecimento ao trabalho que realiza em Católicas pelo Direito de Decidir, pois foi uma de suas fundadoras.

Nas palavras de Regina Jurkewicz, por anos grande companheira em Católicas, enquanto tarefa de toda uma vida, Zeca tem buscado a compreensão da sexualidade e da reprodução humana, com foco especial na autonomia e no direito de decidir das mulheres, através de análises críticas das construções religiosas e de suas lógicas assimétricas de poder. E Ivone Gebara, ressalta a sua ousadia e o impacto cognitivo da lógica do humor, presente em sua crítica social e em sua crítica às religiões.

A construção da Teologia feminista em muito colabora para evidenciar a atuação do patriarcado na subjugação das mulheres. Essas análises críticas valeram-se de métodos de hermenêutica, do estruturalismo e

* Doutora em Filosofia do Direito pela Pontifícia Universidade Católica de São Paulo, onde leciona a disciplina de Filosofia do Direito e a Optativa Direito, Gênero e Igualdade. Coordenadora do Grupo de Pesquisa Direito, Discriminação de Gênero e Igualdade. Integrante do Comitê das Nações Unidas sobre a Eliminação da Discriminação contra Mulher (Comitê CEDAW), de 2005 a 2016, e sua presidente entre 2011 e 2012. Co-fundadora do Comitê Latino-Americano e do Caribe em Defesa dos Direitos da Mulher - CLADEM. 
da psicologia, tornando possíveis releituras da Bíblia, em particular do pecado de Adão e Eva, que permitiram novas compreensões sobre a consciência da opressão de gênero, sobre gênero e sobre o significado da culpa que recai, muito especialmente, em mulheres.

Sendo agnóstica - plena de respeito a todas as pessoas crentes considero o Cristianismo, o lluminismo, a construção da Organização das Nações Unidas (ONU) e seu sistema internacional de proteção aos direitos humanos, bem como os estudos e teorias decoloniais, os movimentos antirracistas, anticlassistas, a luta pelo reconhecimento da população LGBTQIA+ e os múltiplos feminismos, marcos relevantes no caminhar da humanidade rumo à igualdade e à justiça social. Avalio serem os feminismos críticos religiosos imprescindível alavanca na busca de mudanças dos "padrões socioculturais de conduta de homens e mulheres, com vista a alcançar a eliminação dos preconceitos e práticas consuetudinárias, e de qualquer outra índole, que estejam baseados na ideia de inferioridade ou superioridade ou em funções estereotipadas de homens e mulheres".

Durante os doze anos em que participei do Comitê CEDAW da ONU, responsável pelo monitoramento da Convenção sobre a Eliminação de Todas as Formas de Discriminação contra as Mulheres - Convenção CEDAW de 1979 - aprendi que dos seus trinta artigos, é o artigo quinto que versa sobre a cultura e, de forma implícita e diplomática, sobre as religiões, aquele que representa ponto fulcral a ser estrategicamente trabalhado.

$E$, considerando a imbricação existente entre as culturas e as religiões, de tal maneira a parecerem que fundem-se/confundem-se, modificar padrões culturais significaria, em muito, necessariamente, investir contra dogmas discriminatórios sacramentados pelas religiões.

Considero de uma coragem admirável todas as pessoas que ousaram e ousam realizar estudos históricos críticos reveladores de processos sociais que desconstroem a ideia de um sagrado patriarcal e excludente, como Maria José. Assim, viabilizam a ampliação e difusão das diversas possibilidades de compreensão de leituras e narrativas religiosas através dos tempos, como também explicitam certos valores

Comitê CEDAW da Organização das Nações Unidas. Artigo $5^{\text {a }}$ da Convenção sobre a Eliminação de Todas as Formas de Discriminação Contra a Mulher. Genebra, 1979. 
morais judaico-cristãos presentes em nossa sociedade, que favorecem a manutenção das assimetrias entre homens e mulheres, colocando essas últimas em posições de subalternidade.

Os magníficos artigos desta coletânea buscam desmistificar a compreensão dogmática patriarcal de textos canônicos, inclusive da Bíblia, oferecendo interpretações que reconstituem a figura da mulher, considerando-a tão igual e valiosa quanto a do homem.

É instigante constatar a forma com que dogmas, crenças, lendas e mitos são analisados como situados em seus múltiplos contextos históricos, antropológicos, políticos, econômicos e socioculturais. Assim, interpretações apresentadas como verdades intocáveis tornam-se construções humanas passíveis de desconstruções.

Enquanto feminista e professora de Direito, desde finais da década dos 1970, os meus maiores esforços se voltaram à transformação do Direito brasileiro em tudo aquilo que continha de viés patriarcal, machista e discriminatório.

O debate jurídico crítico sobre a relevância da revogação de preceitos normativos construídos numa cultura patriarcal, com forte influência da Igreja Católica, em muito enriqueceu-se e tornou-se mais eficiente com o instrumental valioso das análises críticas religiosas, pois, insistindo, toda mudança legal envolve mudança de mentalidades, o que requer mudança de padrões morais e religiosos discriminatórios presentes historicamente na sociedade brasileira e inculcados em nossas (in)consciências, favorecendo a manutenção das assimetrias entre homens e mulheres.

E Católicas sempre foram as nossas grandes parceiras, pois ao trazer posições críticas sobre os cânones da Igreja Católica que colocam a mulher numa posição de subalternidade, constroem um patamar facilitador do diálogo sobre o direito, em especial, os direitos reprodutivos das mulheres. As suas argumentações, avalio eu, conseguem ir além do nível cognitivo consciente alcançando o inconsciente das subjetividades, quanto a crenças, saberes, afetividades e emoções. Assim alcançando resistências intransponíveis unicamente no nível da racionalidade consciente. 
Vale concluir reproduzindo texto de Maria José, em de mulheres e de deuses²:

"Um discurso inclusivo das mulheres pressupõe a crítica das estruturas patriarcais da sociedade - e das Igrejas - e, portanto, apresenta-se como um discurso que desconstrói o poder dos homens, em todas as esferas sociais, inclusive as religiosas e simbólicas (ROSADO NUNES, 1992, p. 26).

São Paulo, 27 de novembro de 2020

2 ROSADO NUNES, Maria José Fontelas. De mulheres e de deuses. Revista Estudos Feministas, n. 0, 1992, pp. 05-30. 